\title{
STUDY OF LARUNGAN TRADITION IN BENDAR VILLAGE, JUWANA DISTRICT, PATI DISTRICT, CENTRAL JAVA
}

\author{
Eka Nur Jannah ${ }^{1}$, Sunarru Samsi Hariadi ${ }^{2}$, and Subejo ${ }^{2}$ \\ ${ }^{1}$ Agriculture Faculty, Universitas Tidar, \\ J1. Kapten Suparman No.39, Magelang, Indonesia \\ ${ }^{2}$ Agriculture Faculty, Universitas Gadjah Mada, \\ Jl. Flora, Bulaksumur, Yogyakarta, Indonesia \\ Correspondence Email: ekanurjannah@untidar.ac.id
}

Submitted 4 June 2020; Accepted 14 December 2020

\begin{abstract}
ABSTRAK
Larungan merupakan salah satu kearifan lokal yang ada di daerah pesisir, khususnya di Pantai Utara. Larungan merupakan kearifan lokal yang layak untuk diteliti agar anak cucu bangsa Indonesia mengetahui salah satu kearifan lokal Indonesia. Penelitian bertujuan untuk menganalisis upacara adat Larungan yang dilakukan oleh masyarakat di Desa Bendar Kecamatan Juwana Kabupaten Pati. Metode penelitian menggunakan metode deskriptif analitik dengan pendekatan survei. Metode pemilihan tempat dengan metode purposive sampling yaitu di Desa Bendar karena desa tersebut merupakan tempat diselenggarakannya upacara adat Larungan. Respondennya ada 60 nelayan dipilih dengan metode random sampling. Hasil penelitian menunjukkan bahwa Larungan adalah upacara adat yang dilakukan oleh para nelayan sebagai wujud rasa syukur kepada Tuhan Yang Maha Esa atas rejeki yang telah Tuhan berikan berupa hasil tangkapan ikan yang berlimpah. Upacara Larungan juga menjadi media sharing yang berpotensi meningkatkan keyakinan terhadap Tuhan serta dapat memfasilitasi pertukaran pengetahuan, pengalaman, solidaritas dan pelestarian nilai-nilai masyarakat. Upacara adat Larungan setiap tahunnya dilaksanakan pada bulan Syawal hari ketujuh, akan tetapi jika pada hari ketujuh bertepatan dengan hari minggu wage maka pelaksanaan dilakukan pada hari sebelum atau setelah hari minggu wage, karena pada hari minggu wage pernah terjadi kecelakaan saat acara upacara adat Larungan. Sarannya bagi nelayan yang tidak mengikuti Larungan sebaiknya ikut serta untuk meramaikan upacara tersebut untuk melestarikan tradisi, norma, dan nilai budaya lokal Desa Bendar Kecamtan Juwana Kabupaten pati.
\end{abstract}

Kata kunci: larungan, nelayan, upacara tradisional

\begin{abstract}
Larungan is one of the local wisdoms in coastal areas, especially on the North Coast. Larungan is a local wisdom that deserves to be researched so that the Indonesian nation's children and grandchildren know one of Indonesia's local wisdoms. This research was purposed to analyze the Larungan traditional ceremony conducted by community in Bendar Village, Juwana District, pati Regency. The research method uses descriptive analytic method with a survey approach. The method of selecting a place with a purposive sampling method is in Bendar Village because this village is the place for the Larungan traditional ceremony to be held. There were 60 fishermen respondents selected by random sampling method. The research results show that Larungan is a traditional ceremony performed by fishermen as a form of gratitude to God Almighty for the fortune that has been given in the form of abundance fish cathed from the sea. The Larungan ceremony also becomes asharing media that has the potential to increase belief in God and can facilitate the exchange of knowledge, experience, solidarity and preservation of community values. The Larungan traditional ceremony is held every year on Shawwal on the seventh day, but if on the seventh day coincides eith the Sunday Wage, the
\end{abstract}


implementation is carried out on the day before or after the Sunday Wage, because on Sunday Wage had a accident during the Larungan traditional ceremony. The suggestion for fishermen who do not follow Larungan should participate in enlivening the ceremony to preserve the traditions, norms and local cultural values of Bendar Village, Juwana District, Pati Regency.

Keywords: larungan, fishermen, traditional ceremony

\section{INTRODUCTION}

Pati Regency is one of the regencies located in the northeastern part of Central Java province, on the island of Java (north coast Java). Pati Regency has the motto "Pati Bumi Mina Tani”. Many people of Pati work as farmers, fish cultivators, and fishermen. Pati Regency has several sub-districts, one of which is Juwana. Juwana sub-district is famous for its fisheries, especially the number of fish catches. Many people of the Juwana sub-district depend on their livelihood from fishing and they sold the fish products at the local Fish Auction Place (TPI). Local communities usually perform an annual tradition, which is known as Larungan. Larungan is an annual tradition that is carried out a week after Eid al-Fitr as an expression of gratitude to God Almighty and request for blessing and protection for the safety of fishermen at sea by making offerings to the sea. The offerings were paraded by the locals in the fishing village of Bajomulyo and Bendar, Juwana sub-district. Before releasing the offerings into the sea, a ceremony was held at the Unit II Juwana Port which was usually attended by the Regent of Pati and his staff as well as people of the surrounding community.

The culture that has been passed down from generation to generation will become a tradition. Tradition can also be interpreted in a culture specifically or symbolic of the culture itself, for instance, the culture of Eid (month of Shawwal) at the time of Eid alFitr, on the seventh day of Eid al-Fitr, there is a tradition that is routinely carried out by the north coast community in Juwana Subdistrict, namely Larungan. Therefore, tradition becomes the identity of a culture. Many of them honor the communal feast or celebration (slametan) as a mechanism of important social integration or have great respect for their ancestors. (Mulder, 2001). Javanese traditions and actions have always been based on two things. First, to their religious and mystical philosophy of life. Second, on the ethics of life that upholds morals and degrees of life. Myth and magic remain attached to Javanese persons even though the teachings of a religion or pure religion have been accepted for centuries. Modern science and philosophy from the west cannot change traditional Javanese culture (Herusatoto, 2001).

According to Al-Jabiri (in Washil 2013), a tradition in its current meaning refers to the notion of cultural heritage and ideas. In line with the times, the concept of the larungan tradition is seen not only as a remnant or cultural heritage from the past but as part of the perfection of the unity and scope of the culture, which consists of religious doctrine and shari'ah, language and literature, reason and mentality, longings and hopes. This tradition stands as a unity in its cognitive and ideological dimensions, stands as a unity in the foundation of reason and emotional outbursts in the entire Islamic culture. The culture was born before the tradition was created. After it was formed then the culture would be embraced by a group of people and passed on to their descendants.

Larungan tradition is a tradition of sea offerings and as a form of village cleaning ritual ceremony. It is a form of gratitude from the community to God Almighty for the sea products that have been given. The values that exist in the larungan ceremony are the values of cultural education, the value of ethics education in social life, moral values, and religious values (Aryanto, 2013). Larungan is a tradition by making offerings to the sea that affect the surrounding environment, especially nature. The advantages of making offerings to the sea are as an effort to protect 
the marine ecosystem (Yuliamalia, 2019). Larungan is part of a tradition and has an aesthetic value that attracts the locals to be used as a tourist attraction. The procession of this ritual ceremony has two stages including preparation and implementation. Preparation includes the place and the offerings. The implementation includes the opening, handing over the offerings, parade, and making offerings (buceng agung) to the middle of the lake/river/sea. The benefits of the larungan ceremony are a means of requesting protection and safety, enlivening tourism, improving social relations between the locals, and improving the economy of the community (Rusmawati and Suharti, 2016). The values of local wisdom contained in the larungan ceremony are religious values, entertainment values, kinship values, beauty values, and symbolic values. Local wisdom in larungan ceremonies has the power to foster a sense of unity so as to make community brotherhood stronger which makes people live in peace and harmony. The value of local wisdom in larungan ceremonies that upholds the spirit of unity is used by the village government and stakeholders in resolving conflicts that arise in the community (Putra et al., 2017).

Based on the explanation of several research results, it shows that larungan is a customary tradition that generally exists in areas close to lakes, large rivers, and the sea. Larungan activities are held as a form of preservation of ancestral traditions, as a form of gratitude to God, and as a form of activity to attract tourists, both the locals and foreign tourists. Larungan activity contains several values including religious values, which can foster and increase the belief in God for His abundance of fortune. Cultural values as a form to preserve culture from the ancestors.

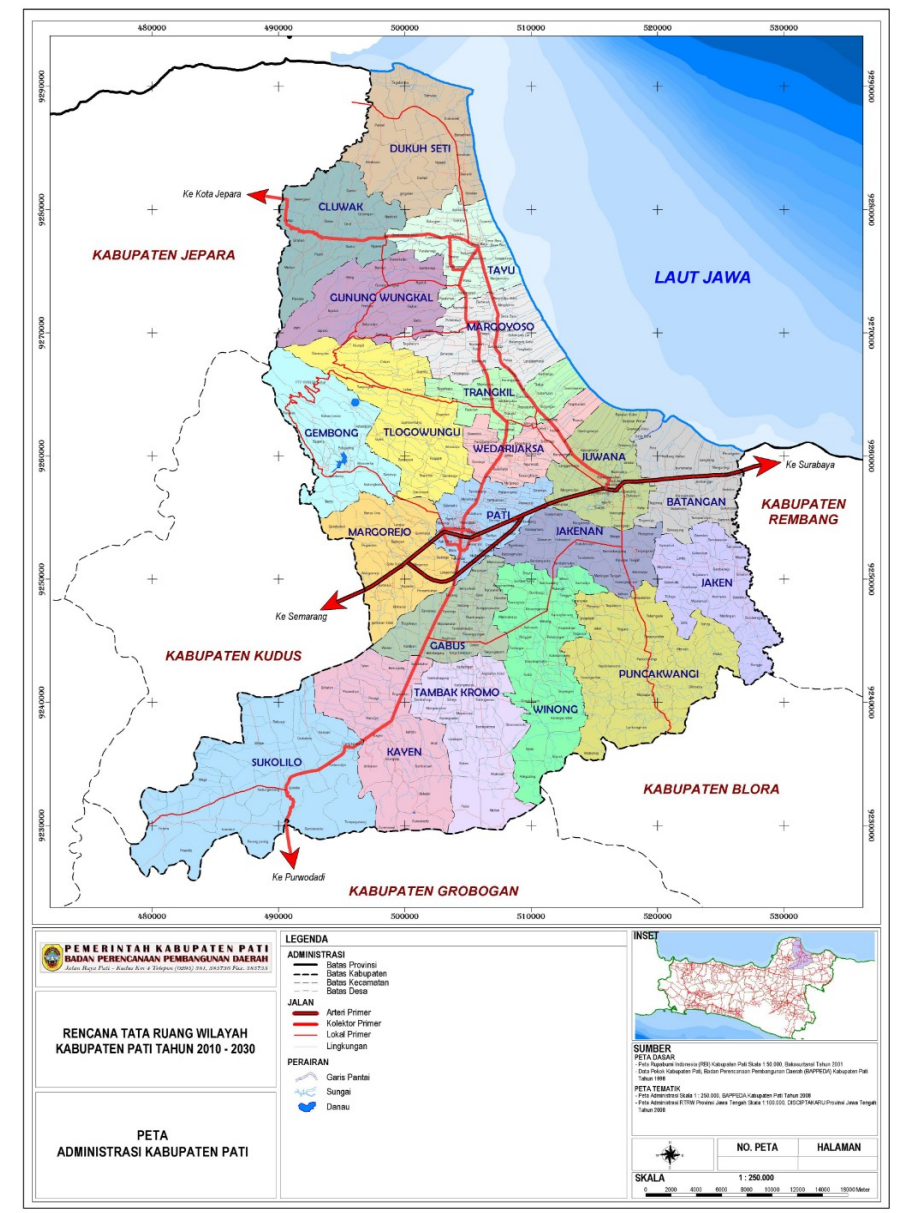

Figure 1. Research Location

Source: http://si.disperakim.jatengprov.go.id/umum/detail_kondisi_geo/23 
Social values as a form of activity that can gather many people so that they can establish a friendship or good relationship. Economic values as a form to provide a place for merchants to display and sell their products to tourists or visitors who watched the Larungan ceremony. According to Yuroidha (2018), the meaning of the larungan ceremony is a form of human concern for the natural environment because the community has been given blessings so that they can survive, as a form of friendship with the community, as a form of advocacy that the fringe people or coastal communities have traditional events and local wisdom that deserve to be preserved. According to Islamic law, Larungan activity is a form of expression of gratitude to God for being blessed with fish catches.

\section{RESEARCH METHODS}

This study uses the basic method of descriptive-analytic with a qualitative approach using survey techniques. According to Singarimbun in Effendi (2012), survey research is a study that takes a sample from one population and uses a questionnaire as the main data collection tool. The sample was selected purposively in the villages of Juwana subdistrict, namely Bendar Village. Bendar Village was chosen because this village is the place where the Larungan traditional ceremony was held. Besides, the majority of the people worked as fishermen and the village was close to the access of the entry and exit of boats.

The selection of respondents was conducted using a random sampling method. Random sampling was performed on a group of fishermen in Bendar Village, as many as 90 people were randomly selected using paper rolls and 60 fishermen were obtained. 60 fishermen were given a questionnaire so that the researcher obtained the desired information. Furthermore, the researcher also had a key person whom the researcher believed knew everything about the Larungan ceremony. The key person was also the head of the fishermen group. The validity of the data was performed by observing the frequency of respondents answering the questions so that the researcher obtained the same answer.

\section{RESULTS AND DISCUSSION}

Fishermen in Bendar village carry out fish catches in two seasons, namely the west season and the east season. The west season is from December to March. The west season is where the wind moves from east to west. The movement of the wind direction is the opposite direction when fishermen are going to sea, so the fishermen have to wait until the wind does not move so strongly. Fishermen are also accustomed to using the sign of the western season by looking at Mount Muria. If Mount Muria is covered in clouds or is not visible then the west season begins. They use the sign of Mount Muria because it is the only mountain closest to it and is located almost parallel to Bendar Village. The eastern season starts from April to September. The east season is where the wind direction moves from west to east. The east season can benefit fishermen because the wind movement is in the same direction as the fishermen's direction, which is sailing east to catch fish. Fishermen are also used to marking the arrival of the eastern season when Mount Muria is clearly visible or not covered by clouds.

Based on the results of the interview with the key person, the fishermen's fish catches in the east season are greater, which is almost double the income in the west season, this is because in the west season the fishermen have to wait several hours until the wind from east to west is not too strong. Fishermen do not dare to go to sea if the weather is bad or the wind is very strong because the wind is in the opposite direction when fishermen are going to sea. They are afraid that if they keep going to sea the ship will capsize. However, it is different in the east season. The wind movement is in the same direction as the fishermen's direction when fishermen are going to the sea. The 
fishermen do not have to wait as happened in the west season and therefore the fishing time at sea is longer than the western season. Community life in Bendar Village is also accustomed to carrying out sea offerings once a year as a form of celebration or a communal feast for fishermen.

The traditional ceremony has been performed since 1960. In the beginning, this ceremony was held when it coincided with the fishermen's day and as a form of gratitude for the abundant sea products. Larungan was first performed in Bendar Village, where researchers conducted research. After that, it was followed by several other villages such as Bajomulyo, Bumirejo, Jepura, and Banyumancing. In 1969, the larungan was held to coincide on Wage Sunday (Javanese calendar). During the implementation of the ceremony, a major disaster occurred. The ships carrying visitors to the sea had accidents. Ships carrying visitors to watch the process of releasing offerings at sea and suddenly there is a rope with a transverse direction preventing the ship from moving forward and at that time there is a large current from the opposite direction so that the ship's captain cannot avoid the current and finally the ship capsized causing many casualties. The local communities have not held the Larungan ceremony on Wage Sunday until now because they fear the same thing will happen as in 1969. If the seventh day of Idul Fitri coincides with Wage Sunday, the sea offerings can be performed before Wage Sunday or after Wage Sunday.

Based on the events that have been experienced by the community in Bendar Village, they carried out activities in order to celebrate or communal feast, and an expression of gratitude to God. This is according to the statement of Aryanto (2013) that "larungan tradition is a form of expression of gratitude to God for the fortune that has been given because of the fish catches". Javanese society still has strong Javanese cultures as a form of Javanese cultural preservation so that it does not become extinct. Larungan tradition is a form of ancestral culture that has been dying out gradually over time so that it is rare and needs to be preserved. Preservation can be carried out directly by carrying out these larungan activities and by recording it in writing so that the public knows that Indonesia has a unique tradition of coastal areas that are carried out every year. Larungan is a form of local wisdom that exists in coastal communities.

Larungan sea offerings activities in Bendar Village are carried out once a year. The activity began with the greetings from the Pati Regency Government, the Village Head, the Chair of the Committee, and prayers to accompany the cukrik (the ship miniature) and offerings that parade around the village before being released into the sea. The cukrik is decorated with coconut leaves, red and white ribbons, and red and white flags and contains offerings. The offerings contain seven forms of flower, young coconut, water jug (Kendi), and black goat's head. The meanings include:

1. Cukrik is a boat or ship used by fishermen to earn a living, namely catching fish in the sea.

2. Offerings (Sesaji) describe the composition of the earth.

3. Janur describes the human who was born into the world.

4. Red and white ribbons and red and white flags are symbols of the Republic of Indonesia.

5. The seven forms of the flower represent different human lives, including their nature, character, ambition, strength, and ability.

6. Young coconut describes the round globe.

7. Water Jug (Kendi) is a person living in the world only to stop by to drink (life in the world is only temporary).

8. The head of a black goat is a human being who has a strong determination to always try and work hard and does not give up easily in making a living to fulfill their daily life.

The fishermen participated in Larungan traditional ceremony. This event is held by a committee consisting of village officials, fishermen, and community leaders. 
The process of the Larungan traditional ceremony begins by placing the offerings on a miniature ship, then handing it over to the Village Head, and handing it over to the committee. After that, it is paraded around Bendar Village. The cukrik which has been filled with offerings is then put on the mother ship to be brought out to the sea. When arriving at the sea, joint prayer is carried out and then releases the cukrik and offerings into the sea.

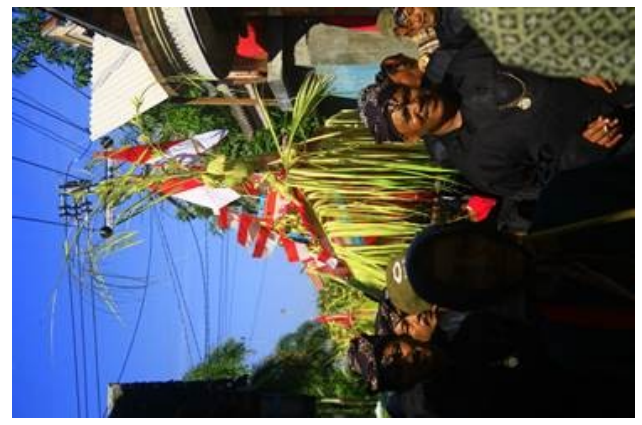

Figure 2. Rituals of Miniature Ship Parade (Cukrik) and Larungan Offerings

Figure 2 explains that the cukrik containing the offerings for the Larungan ceremony are paraded around Bendar Village. The majority of the people of Bendar Village, from children to the elderly attend the Larungan ceremony. In the picture, men are wearing black clothes which are the uniforms of the Committee of Larungan ceremony.

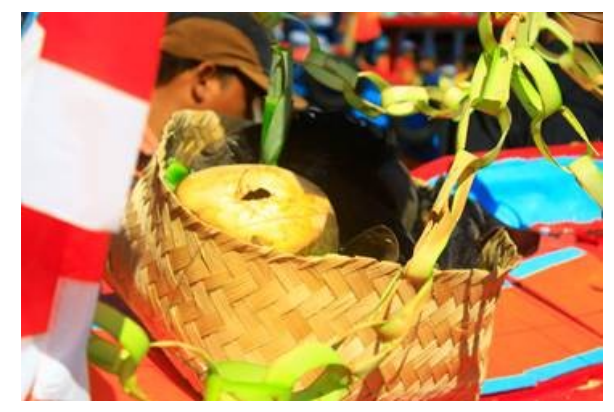

Figure 3. Larungan offerings

Figure 3 describes the Larungan offerings consisting of goat's head, young coconut, jug filled with water, and several types of flowers placed in a "besek" (smallsized covered square basket of plaited bamboo). They have been using goat heads as offerings since their ancestors and coastal communities have preserved them until now.

Figure 4 shows the fishing community gathered around the ships and offerings to pray together (in Javanese) before being released into the sea. The essence of the prayer is "mugo-mugo dianakno upacara iki, hasil laut nelayan iso nambah, berkah, lan ora ono alangan opo-opo saben neng laut, mulih selamet gowo hasil akih", which means that hopefully with the implementation of this Larungan ceremony, the fish catches by fishermen are increasing, blessed, and there are no obstacles in carrying out activities at sea and returning home with lots of fish.

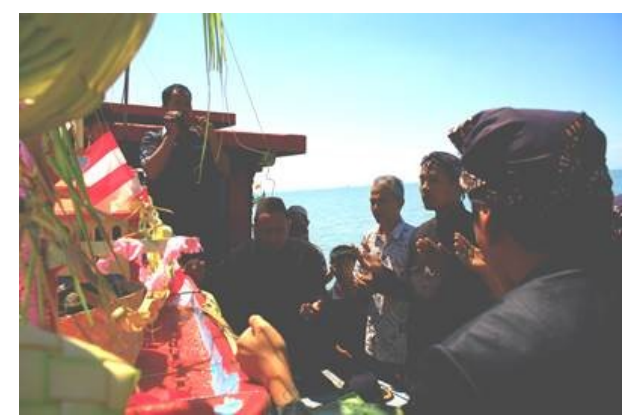

Figure 4. Prayers Together Before the Miniature Ships and Offerings are Released into the Sea

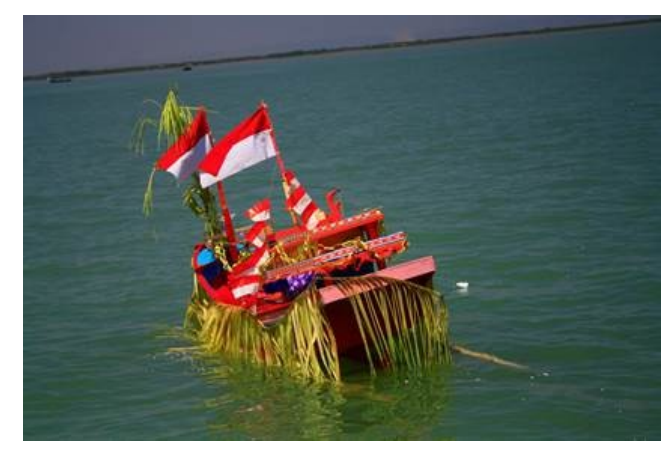

Figure 5. Miniature Ships (Cukrik) and Offerings are Released into the Sea

Figure 5 shows the ships and the offerings that have been released into the sea. The release was carried out after the prayer was held together. These cukrik and offerings are presented by the people of Bendar Village as gratitude so that they can get abundant fish and given protection and safety. When the mother ship (which was carrying cukrik and offerings) arrived in Bendar Village, some people deliberately took the offerings and the 
miniature ships that had been released into the sea, then the committee replaces them with the new miniature ships. There are no sanctions whatsoever for people who take the cukrik and even they compete for it because those who succeed in taking the cukrik will get some money from the committee. The money is a form of gratitude for taking the cukrik because the cukrik can be used again next year.

Some fishermen did not participate in Larungan when the traditional ceremony was held. However, they still contributed in the form of material (fees) for the Larungan ceremony. The reason they did not participate in the Larungan traditional ceremony was that there was another job that could not be left behind or they prefer to stay at home with their relatives because at the time of the Larungan traditional ceremony it was still at the time of Eid Al-Fitr, which is on the seventh day of Eid, and some also said: "Other fishermen have participated and they have represented those who did not participate". Another fishermen's response to those who do not participate in the Larung ceremony is to tolerate those who do not participate because it coincides with Eid alFitr. However, in the long term, it will cause a difference in the spirit between fishermen who take part in Larungan and those who do not. Therefore, it will increase the motivation of the fishermen who take part in Larungan to continue to preserve the Larungan culture because they feel they owned the culture and consider it important to continue to carry out the Larungan traditional ceremony as a form of gratitude to God. In addition, those who participate in the Larungan ceremony can exchange ideas, share experiences with other fishermen about the latest things related to new technological innovations of marine fisheries. For the community, the Larungan traditional ceremony also has benefits to increase the income of the surrounding community. When the Larungan event was held, many people from outside Bendar Village and Bendar Village people themselves took advantage of the event to sell ornaments, food, drinks, and souvenirs because many people from other villages visited to watch the Larungan ceremony. Information on the Larungan traditional ceremony spread throughout Pati Regency starting from word of mouth. However, nowadays there is special coverage of the Larungan ceremony on local television in Pati Regency, namely Simpang Lima Television.

\section{CONCLUSIONS}

1. Larungan is a traditional and cultural ceremony carried out by the community of Bendar Village as a form of gratitude to God Almighty. The Larungan traditional ceremony can be a potential sharing medium to increase the belief and can facilitate the exchange of knowledge and experience, as well as fostering solidarity between people.

2. Larungan traditional ceremony as a place to introduce the customs of coastal communities to the public and as a form of preservation of community values and norms.

3. Larungan traditional ceremony also has benefits to increase the income of the surrounding community by selling trinkets or ornaments, food, drinks, and souvenirs.

4. Fishermen who do not participate in the Larungan ceremony should not only contribute to material things but also participate in enlivening the ceremony to preserve the traditions, norms, and local cultural values of Bendar Village, Juwana subdistrict, Pati Regency.

\section{REFERENCES}

Aryanto, A. 2013. Kajian Folklore dalam Tradisi Larungan di Desa Kertojayan Kecamatan Grabag Kabupaten Purworejo. Jurnal Pendidikan, Bahasa, Sastra, dan Budaya Jawa 3(6).

Dinas Perumahan Rakyat dan Kawasan Pemukiman Jawa Tengah. 2019. Profil kondisi geografis Kabupaten Pati. http://si.disperakim.jatengprov.go.id/u 
$\underline{\text { mum/detail kondisi_geo/23. Accessed }}$ on 12 August 2019.

Effendi, S. 2012. Metode Penelitian Survei. Jakarta. LP3ES.

Herusatoto, B. 2001. Simbolisme dalam Budaya Jawa. Yogyakarta. Hanindita Graha Widia.

Mulder, N. 2001. Mistisisme Jawa. Yogyakarta. LKIS.

Putra, T. A. H., A. Tinus, and N. Yusuf. 2017. Kearifan lokal upacara larungan telaga ngebel dalam membangun harmonisasi sosial. Jurnal Civic Hukum 2(2): 6577.

Rusmawati and Suharti. 2016. Tradhisi larungan buceng agung di Telaga Ngebel sebagai sarana penarik wisatawan. Jurnal Penelitian Humaniora 21(2): 99-108.

Washil, I. 2013. Dilema tradisi dan modernitas telaah atas "Kritik Nalar Arab" Muhammad Abid Al-jabiri. Jurnal Khatulistiwa-Journal of Islamic Studies 3(2): 101-112.

Yuliamalia, L. 2019. Tradisi Larung Saji sebagai Upaya Menjaga Ekosistem di Wisata Telaga Ngebel Ponorogo (Studi Literatur). Jurnal Agastya 9(2): 135145.

Yuroidha, I. 2018. Studi upacara larung singai pada masyarakat Islam di Karang Pilang Surabaya. Thesis. Fakultas Ushuluddin dan Filsafat, Universitas Islam Negeri Sunan Ampel, Surabaya. 